INTERNATIONAL DESIGN CONFERENCE - DESIGN 2018

https://doi.org/10.21278/idc.2018.0458

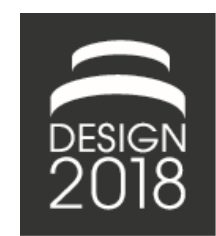

\title{
HOW TO SELECT APPROPRIATE STIMULATION MECHANISMS TO PERFORM AN ECO-IDEATION SESSION?
}

\author{
B. Tyl, F. Vallet and O. Pialot
}

\begin{abstract}
The generation of eco-innovative ideas requires the development of specific heuristics or stimuli. If several types of heuristics have been elaborated in innovation -and eco-innovation-, the selection of appropriate heuristics adapted to an industrial problem for ideation -and eco-ideation- have not been addressed. This paper explores three methods for selecting heuristics called Eco-ideation Stimulation Mechanisms (ESM) for an energy-based case: (1) an examination of environmental issues; (2) a direct screening of the problem through the ESMs; (3) an examination of inspiring cases.
\end{abstract}

Keywords: eco-ideation, eco-ideation stimulation mechanism, eco-innovation, design creativity, design methods

\section{Introduction}

World population is expected to rise from 7.6 billion in 2017 to $8.4-8.7$ billion in 2030 and eventually 9.4-10.2 billion in 2050 (United Nations, 2017). Besides demographic pressure, environmental stress and changing modes of value creation by business are indeed drivers of sustainable development (Fussler and James, 1996). Aligned to these objectives, eco-innovation "integrates the long-term trends that will transform consumption, value creation and material processes" (Fussler and James, 1996).

For Hofstra and Huysingh (2014), eco-innovation has to be envisaged thanks to a new interaction paradigm between humans and nature, at odds with deeply rooted anthropocentric ideas. Their definition of eco-innovation is hence "inventions, designs and new solutions for fulfilling human's and nature's needs in ecologically effective ways" (Hofstra and Huysingh, 2014). Eco-innovation often starts from ill-defined problems, i.e. problems with various objectives, with a systemic approach, and requiring different ways of exploration (Jonassen and Hung, 2008; Hocking and Vernon, 2017).

Moreover, literature on innovation explains the crucial role of problem finding and its consequences on the creativity of the design team (Hocking and Vernon, 2017). It ca ne argued that problem finding, or more generally speaking, the starting point of an eco-ideation process, requires some techniques to foster the generation of relevant ideas. Nevertheless, despite various researches on stimuli, or heuristics (Goldschmidt and Smolkov, 2006; Yilmaz et al., 2015), Gonçalves et al. (2016) claim that the inspiration process, that is to say designers' selection of stimuli during the development of a design problem, has not really been investigated in research. Although various contributions on eco-ideation and ideation stimuli (or heuristics) have been made in the past years, the concern of selection of stimuli prior to the eco-ideation process has also been overlooked. The overall research question addressed in the paper is expressed as follows: "How to support the identification of relevant heuristics during the problem framing of an eco-ideation process?" Section 2 addresses the development of stimuli in innovation and eco-innovation, and the need to connect the selection of stimuli to the problem finding phase. Section 3 documents the experimental 
protocol to test three methods based on Eco-ideation Stimulation Mechanisms (ESM) on an energyrelated industrial case. Section 4 focuses on the results of the three approaches. Conclusions and future developments around the ESM eco-ideation process are proposed in Section 5.

\section{Previous research in eco-ideation}

This paper proposes to explore the starting point of an eco-ideation process that is to say the stage when the design team develops an eco-ideation strategy from an initial design brief. To do so, this paper relies on previous researches about (1) eco-ideation stimulation mechanisms to generate eco-innovation (Tyl et al., 2016) and (2) the analysis of case studies to support eco-innovation (Yang and Chen, 2011, 2012; Vallet et al., 2017).To conclude the section, the previous results are revisited in order to formalize a new research question.

\subsection{The development of Eco-ideation Stimulation Mechanisms}

The central part of an innovation process is the creativity stage or ideation. Within an environmental perspective, eco-ideation is the stage when designers have to generate ideas with a high potential of environmental impact reduction. Eco-ideation has already been studied in literature. Cluzel et al. (2016) present the eco-design strategy wheel from (Brezet and Van Hemel, 1997) to generate eco-innovative ideas. Bocken et al. (2011) develop a specific eco-ideation tool focused on greenhouse gas emissions reduction. Tyl et al. (2014) stated the relevance to use eco-ideation tools with an intermediary, or meso-level mechanism, to compromise between a systemic vision and a possible technical concretization (e.g. EcoASIT tool). From this analysis, the authors developed a set of Eco-ideation Stimulation Mechanisms (ESM) to support eco-ideation sessions, allowing to have a systemic vision of the problem, while efficiently stimulating the design team to cover the whole eco-innovation process. Basically, the ESM in an easy, systematic and actionable manner for designers to ideate, inspired by the concept of tiny or micro-tool.

To develop the set of ESM and to cover the eco-innovation challenges, the conceptual model of ecoinnovation detailed in the UNEP eco-innovation manual was taken as a backbone (O'Hare et al., 2014). The development of a first set of 8 ESM, as well as a detailed example of an ESM "Innovate through biomimicry" was described in (Tyl et al., 2016). An iterative process was then conducted to formalize an updated set of 7 mechanisms, presented in Table 1.

Table 1. Set of Eco-ideation Stimulation Mechanisms

\begin{tabular}{|l|l|}
\hline $\begin{array}{l}\text { Innovate with } \\
\text { stakeholders }\end{array}$ & $\begin{array}{l}\text { This ESM raises the question of the stakeholder network, through the value } \\
\text { creation for the users, the environment, society, and all other relevant actors } \\
\text { value creation for all stakeholders }\end{array}$ \\
\hline $\begin{array}{l}\text { Innovate through } \\
\text { biomimicry }\end{array}$ & $\begin{array}{l}\text { This ESM question the similarities between man-made industrials practices } \\
\text { and natural strategies of development at several system levels (organ, } \\
\text { organism, ecosystem). }\end{array}$ \\
\hline $\begin{array}{l}\text { Innovate through } \\
\text { sustainable mode } \\
\text { of consumption }\end{array}$ & $\begin{array}{l}\text { This ESM raises the question of the unsustainable use of products/services } \\
\text { and how the system can fit the system to end users and territorial specificities } \\
\text { (skills, resources, et.) }\end{array}$ \\
\hline $\begin{array}{l}\text { Innovate through } \\
\text { Systems }\end{array}$ & $\begin{array}{l}\text { This ESM raises the question of optimizing the functionality of the materials } \\
\text { and energy consumed by the system (use intensity, dematerialization) and of } \\
\text { dissociating the product property and the consumption. }\end{array}$ \\
\hline $\begin{array}{l}\text { Innovate through } \\
\text { territorial } \\
\text { resources }\end{array}$ & $\begin{array}{l}\text { This ESM question the integration of territorial capitals in design strategy: } \\
\text { natural capitals, industrial ecosystems, social capitals and anthropic capitals. }\end{array}$ \\
\hline $\begin{array}{l}\text { Innovate through } \\
\text { circularity }\end{array}$ & $\begin{array}{l}\text { This ESM question the different ways to design a product in closed loop (of } \\
\text { material, energy, information). It also question the question of recycle, repair, } \\
\text { upgradability }\end{array}$ \\
\hline
\end{tabular}




\subsection{The analysis of case studies as an approach to eco-innovation}

Eco-innovation remains an ill-defined concept. The examination of relevant eco-innovative cases can be seen as an opportunity to define a common language into the design team in companies, but also to stimulate the generation of innovative ideas. Some academic works have already been proposed accordingly (Hellström, 2007; Carrillo-Hermosilla et al., 2010) and they explore the diversity and the different levels of eco-innovation through the analysis a set of eco-innovative case studies processes. Bocken et al. (2014) used the same approach to characterize sustainable business models archetypes, identifying several good practices. In Vallet et al. (2017), an experimental test was organized to elicit how a case-based approach can reveal practical criteria of eco-innovation. The analysis of ecoinnovation cases appear to be interesting intermediary objects to favour a common understanding of eco-innovation challenges, and to extract criteria for eco-innovation.

Moreover, it can be noted that the application of case-based reasoning (CBR) to sustainable product development is more and more addressed in literature (Romli et al., 2015). For instance, Yang and Chen (2011) proposed to enhance preliminary eco-innovation steps by integrating CBR and the TRIZ creativity method. In Yang and Chen (2012), simple life cycle assessment was added to CBR and TRIZ to compare the environmental performances of the previous and the new solution.

\subsection{A gap in the selection of appropriate heuristics in eco-ideation}

A first step in eco-ideation is the identification of the issues and the right way to start the process with appropriate ESMs. As previously said, eco-innovation often starts from ill-defined problem. To explore these problems, designers often use cognitive strategies, also called "ideation mechanisms", "design heuristics", "stimulation mechanisms" (Mulet and Vidal, 2008; Tyl, et al., 2014; Yilmaz et al., 2015). Vasconcelos and Crilly (2015) proposed a useful state of the art of external stimuli variables studied in literature. They underlined that that stimuli must be neither too near nor too far from the design task, in order to generate creative solutions. Therefore Goldschmidt and Smolkov (2006) saw that problems were more or less sensitive depending of the presence of stimuli. Examples as stimuli can have either positive or negative effects on opening the "design space", being inspirational sources or on the contrary restricting the generation of ideas by replicating existing examples (Gonçalves et al., 2014). Gonçalves et al. (2016) also analysed how designers selected the stimuli before ideation processes. They showed that this selection can be based on relevance (for the design task), the recognition (so they are already aware of the content of a stimulus), the verification and the curiosity. But this research is based on a database of stimuli, so the search process of the stimuli (with keywords) is particularly important.

In our research, a set of 7 specific Eco-ideation Stimulation Mechanisms was predefined, so that the design team can quickly have an overview of the whole set. This paper aims to answer a more focused research question: "How to support the identification of the relevant Eco-ideation Stimulation Mechanisms during the problem framing of an eco-ideation process?"

\section{Research method}

This section presents the rationale of the empirical setting to investigate the process of selection of the ESMs prior to an eco-ideation session. A qualitative approach is selected, as it is appropriate to understand the "nature of phenomena" (Blessing and Chakrabarti, 2009, p. 79). In the study, we are indeed interested in arguments and opinions exchanged between a limited number of participants, in order to make decisions about the choice of eco-ideation stimulation mechanism and to reframe problems. For the qualitative analysis of the outcomes, sentences and questions associated with problem reframing were reported. For the qualitative evaluation of the task, a SWOT (Strengths, Weaknesses, Opportunities and Threats) analysis was conducted by participants, and then by the researchers, to identify the important factors of success and failure of the three different methods. The SWOT approach was previously used (Tyl et al., 2015) to analyze eco-design workshops. 


\subsection{Description of the test}

In November 2017, a one-day test was organized during a workshop dedicated to eco-innovation practice. The event was advertised as a workshop to present, co-design and test the ESMs with the members of the French network EcoSD (Eco-design of Sustainable Systems). Three real case studies proposed by industrial members were used, one of which is reported in the paper. For this test, 20 participants were recruited on a voluntary basis via the network (among which 6 industrials, 2 consultants, 2 technical centre engineers, 10 academics). All participants had experience in ecodesign, eco-innovation, or sustainability. The research method is a participant observation of team work. Three authors were involved in the experiment as facilitators for the groups. Participants were divided into three similar groups (in terms of number of industrials, academics, and gender parity). Data collected are all the documents produced along the session. An online questionnaire was sent just after the test, and left open for one week. The experimental test consisted in a three-hour workshop as followed:

- Step 1: Presentation of the set of ESM, the objective of the workshop, the design task by the industrial initiator (45 $\mathrm{min})$;

- Step 2: Implementation of a different selection method in each group (1 h $30 \mathrm{~min}$ );

- Step 3: Evaluation of the methodology by each group (30 min);

- Step 4: Collective discussion (15 min).

\subsection{Methods}

The rationale to test the 3 different methods relies on eco-innovation literature.

Group 1: The group had to identify the relevant ESMs described in Table 1 through an analysis of the environmental problems from the design brief. In the DRM (Design Research Methodology) one control group is required (Blessing and Chakrabarti, 2009). Group 1 was considered as the control group because the analysis of environmental problems is a common stage in eco-innovation. The objective of the approach was to identify environmental problems and then to link them to the ESM in three steps. The first step was to describe the industrial case according to: (1) the technical elements of the system (operational modules, flows), (2) the description of the value chain with the different stakeholders, (3) the identification of the significant elements on the life cycle, and (4) the description of the constraints that come from the new industrial context. The second step consisted in translating the main elements identified in step 1 into 3-4 environmental problems. To do so, an individual sheet (Figure 1), was provided to each participant. The pitfalls to avoid in order to achieve good environmental performance were listed by the authors with an approach in spirit of FMECA method (i.e. Failure Modes, Effects and Criticality Analysis). These environmental problems are formulated as "Avoid X" The third step consisted in summing, the environmental problems and deducing ESMs using the Problem-ESM relationship (Figure 1). To finish, a collective discussion was done to select 2 or 3 ESMs.

Group 2: The group had to identify relevant ESMs through a systematic reformulation of the design brief through each ESM described in Table 1. Each participant had to reformulate the design brief for each ESM. Secondly, the group was invited to collectively discuss their reformulation and then to select the ESMs they consider the more relevant for the design task through a spider diagram.

Group 3: The group had to identify relevant ESMs through inspiring case studies. The objective was to select a sample of relevant cases from a pre-defined set of 14 examples (Table 2), and in a second step to deduce the most insightful ESM choice for the industrial brief. The 14 cases, related to energy or community topics, were selected by the authors from a constructed database of 300 inspiring cases, under the assumption of usefulness of case studies to foster eco-innovation (see Section 2.2). Moreover, each case was previously connected to one main ESM by two of the authors. The process started with a rapid individual reading through cases, followed by an individual selection of 3-4 cases with justifications (one case being reported on one sticky note). The third step consisted in a collective clustering of the selected cases into four categories. Lastly, participants were invited to debate on categories and choose two ESMs that were representative of the selection. 


\begin{tabular}{|c|c|c|c|}
\hline & $\mathrm{N}^{\circ}$ & Environmental Problematic & ESM \\
\hline \multirow{7}{*}{$\begin{array}{c}\text { Phase } \\
\text { "Extraction- } \\
\text { Manufacturing- } \\
\text { Distribution- } \\
\text { Design" }\end{array}$} & 10 & Avoid material toxicity & $2 / 7$ \\
\hline & 11. & Avoid the use of "newly extracted" material & 1 \\
\hline & 12 & Avoid the no-efficiency of Conceptual model or techno & $2 / 7$ \\
\hline & 13 & Avoid the toxicity and/or no-efficiency of manufacturing process & 4 \\
\hline & 14 & Avoid a high level of "materialization" of value (lots of hardware, few software and humanware) & $2 / 7$ \\
\hline & 15 & Avoid "global" and centralized circuits & $1 / 5$ \\
\hline & 16 & Avoid considering the destroyed and missed values & 1 \\
\hline \multirow{5}{*}{$\begin{array}{l}\text { Phase "Use- } \\
\text { Maintenance" }\end{array}$} & 20 & Avoid usage drifts & 3 \\
\hline & 21 & Avoid system that loses value over time and / or with low lifetime & 6 \\
\hline & 22 & Avoid low intensity of use & 4 \\
\hline & 23 & Avoid the no-adjustment of the functional set of the System / user needs (quantitative \& qualitative) & 3 \\
\hline & 24 & Avoid the unsustainable consumption habits of the client-user (no frugal, disposable product, not local, etc) & 3 \\
\hline \multirow{4}{*}{$\begin{array}{c}\text { Phase "End-of- } \\
\text { Life" (EOL) }\end{array}$} & 30 & Avoid waste due to non-treatment EOL of used products & 6 \\
\hline & 31 & Avoid waste due to inefficient EOL collection & 5 \\
\hline & 32 & Avoid the transfer of ownership to foster EOL collection & 4 \\
\hline & 40 & Another environmental problem & - \\
\hline
\end{tabular}

Figure 1. Document support for the group 1

Table 2. Sample of inspiring cases for group 3

\begin{tabular}{|l|l|}
\hline Case study & Short description \\
\hline 1/ AQUAKIN & $\begin{array}{l}\text { Mini hydro-electric power stations to transform the smallest trickle of water from the } \\
\text { pipes into electricity. }\end{array}$ \\
\hline 2/ WINDSTALK & Giant reeds which produce piezoelectricity thank to the wind. \\
\hline 3/ POWERWINDOW & Window covering that transforms the glass into a solar panel. \\
\hline 4/ OBIFLAM & Heat logs manufactured from sawdust (80\%) and coffee grounds (20\%). \\
\hline 5/ GLOWEE & $\begin{array}{l}\text { Biolighting system without electricity consumption, thanks to natural properties of } \\
\text { bioluminescent cells. }\end{array}$ \\
\hline 6/ DEFAB & $\begin{array}{l}\text { Water heating system thanks to the energy released by computer and processors } \\
\text { systems. }\end{array}$ \\
\hline 7/ SUNSALUTER & Low Tech solar panel trackers, without motorization (gain 40\%). \\
\hline 8/ OCTOPUSEA & $\begin{array}{l}\text { Floating buoy-power station exploiting the energies of the swell, the ocean current, the } \\
\text { wind and the sun. }\end{array}$ \\
\hline 9/ EFFIFUEL & Deployment of services around the tire, for efficiency of professional fleets. \\
\hline 10/ SMIILE & $\begin{array}{l}\text { Social network to share product and services between inhabitants from the same city or } \\
\text { district. }\end{array}$ \\
\hline 11/ Brooklyn & $\begin{array}{l}\text { Community mini smart grid in order to combine renewable energy and sharing } \\
\text { economy. }\end{array}$ \\
\hline MicroGrid & Website of "Crowd Timing" to engage people in solidarity actions. \\
\hline 13/ LEVISYS & Solution to smooth the production of renewable energies. \\
\hline 14/ AMIE & 3D printed "house and car" set, exchanging energy according to situations and needs. \\
\hline
\end{tabular}

\subsection{Design task: How to develop a self-consumption offer for sustainable energy}

One partner involved in the research proposed a design brief related to the energy sector. I-ENER is a citizen company created in 2015, in the French Basque Country, which aims at developing renewable energy project in the Basque territory through citizen funding. In order to develop the project, this company involves citizens, shareholders of the company, and Bask city councils who want to develop renewable energy projects in their territories The company involves about 200 shareholders and has developed six mains photovoltaic projects until now. The business model of I-ENER consists in investing in renewable energy and then sell the energy to the national electric network with a preferential price (regulated by the government). In 2016, the French government voted a specific law to encourage 
self-consumption of renewable energy (JORF, 2016). It is part of a more global evolution of the European law that should provide citizens with a greater control over their production and consumption of energy. Therefore, the design task was to propose a new offer within the auto-consumption context. This industrial case was selected because it involves various levels of issues: a product level (for example the use of photovoltaic panels), a business model level (the proposal of a new offer), a strategic level (the future of the company).

\section{Results: Choosing appropriate eco-ideation mechanisms}

\subsection{Method 1 (baseline): Identification of environmental problems}

The environmental issue approach was conducted with a group of 6 people, who translated the industrial case I-ENER following the representation in 4 blocks. From this work, participants individually translated the significant elements identified into 3-4 environmental issues and deduced in group discussion the most promising ESMs to explore. The Figure 2 presents the results of choice of environmental issues to translate the I-ENER case (step 2), the conversion of these issues into ESM to be mobilized (step 3) and finally the choice of the 3 most promising ESMs after group discussion. The votes are aggregated according to the ESM translation of each environmental problem. For instance the problems 23 and 24 are related to ESM 3 and collect respectively 3 and 6 votes; so the aggregated vote of ESM 3 is 9. In order of decreasing importance, "Innovate with stakeholders", "Innovate through sustainable consumption modes" and "Innovate through territorial resources" were selected. The ESM "Innovate through circularity" was considered interesting, but outside of the scope of I-ENER.

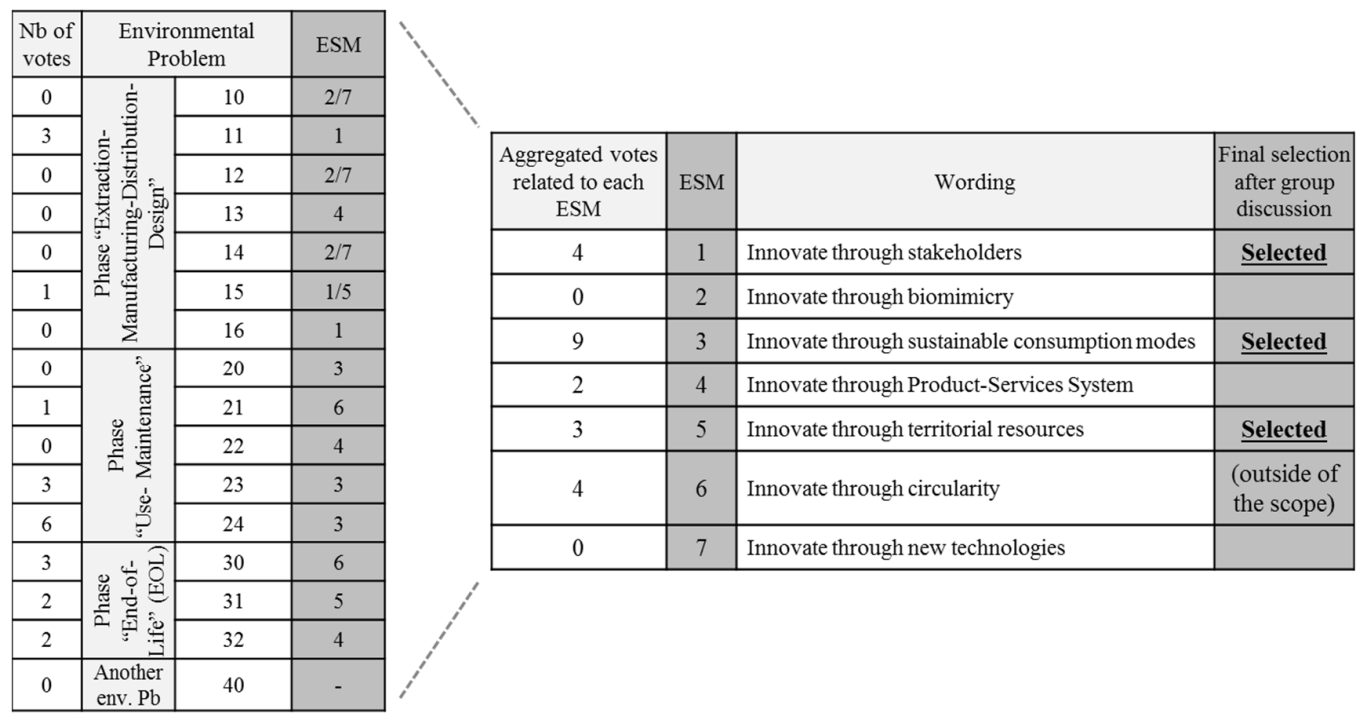

Figure 2. Environmental issues and most promising ESMs selected in group 1

Table 3 draws some conclusions concerning this method. This method was considered relevant in acquiring a better comprehension of the industrial subject and in identifying environmental dimensions. In fact, the representation in four blocks makes it possible to describe the existing context and to consider the impact of new constraint / opportunity (self-consumption in I-ENER case). The selection process the most relevant environmental issues according to the subject treated was considered as "fun". Nevertheless, the wording of environmental issues can be improved. Certain issues are transverse and it would be a good thing to show that. Lastly, the requirement of a "coach" was perceived as a weakness. The main threat of this method is the feeling that choices are based on the experience and educated guesses. Nevertheless, the results presented in Figure 2 show a convergence among the individual choice of participants. It was noted that if the discussion time for choosing the ESMs is too short, the participants do not have time to confront the arguments for or against their choices. 
An opportunity to enrich the method is to encompass the social and societal issues. Today, the ESM set is committed to environmental issues, the societal/social aspects being a work perspective.

Table 3. SWOT analysis for the group 3 - identification of environmental problems

\begin{tabular}{|c|c|}
\hline Strengths & Weaknesses \\
\hline $\begin{array}{l}\text { Representation process of the industrial subject } \\
\text { interesting to identify problematic dimensions. } \\
\text { Fun process to choose the most relevant } \\
\text { environmental issues according to the subject } \\
\text { treated, among a wide range of proposals. }\end{array}$ & $\begin{array}{l}\text { The presentation of the wording of environmental issues } \\
\text { can be improved (choice of terms, level of explanation, } \\
\text { transverse points). } \\
\text { Process that requires a facilitator. }\end{array}$ \\
\hline Opportunities & $\begin{array}{l}\text { Threats } \\
\end{array}$ \\
\hline $\begin{array}{l}\text { The process could be extended to social / societal } \\
\text { issues. }\end{array}$ & $\begin{array}{l}\text { The choice of environmental issues seems to be made } \\
\text { thanks to the experience. } \\
\text { If the discussion time for choosing the ESM is too short, } \\
\text { then the participants do not have time to confront the } \\
\text { arguments for or against the choice of the ESM. }\end{array}$ \\
\hline
\end{tabular}

\subsection{Method 2: Direct examination of Eco-ideation Stimulation Mechanisms}

After reading the description of the set of ESM, each participants had to define a problem, or to refine the design task, according to each ESM. Some reformulation proposed par participants are presented in Table 4. Then, after a collective discussion about the different reformulations, participants selected their two more relevant ESM (Table 4). The ESM "Innovate through sustainable modes of consumption" and "Innovate through territorial resources" were the most selected ESMs. Nevertheless, except for the ESM "Innovate through biomimicry" and "Innovate through new technologies", the votes are quite homogeneous and not very distant. This can be explained because the method of reformulation of case studies proposes to extend the design task to new opportunities (How to integrate the end-of life of photovoltaic panels in the business model? How to directly inject low carbon energy on time on the electric network to avoid the use of high carbon energy?) so that participants can have a more systemic view of the problem.

Table 4. Reformulation of the issues for group 2

\begin{tabular}{|l|l|c|}
\hline \multicolumn{1}{|c|}{ ESM } & \multicolumn{1}{|c|}{ Reformulation of the issues } & $\begin{array}{c}\text { Nb of } \\
\text { votes }\end{array}$ \\
\hline $\begin{array}{l}\text { Innovate with } \\
\text { stakeholders }\end{array}$ & $\begin{array}{l}\text { Adaptation of the offer to be profitable for all stakeholders? How to widen the } \\
\text { stakeholder network thanks to self-consumption project? How to sensitize public } \\
\text { actors in renewable energy? How to include all the stakeholders for a self- } \\
\text { consumption project? How to make the most of an inconstant network of actors in } \\
\text { an evolving legislative context? }\end{array}$ & 3 \\
\hline $\begin{array}{l}\text { Innovate through } \\
\text { biomimicry }\end{array}$ & $\begin{array}{l}\text { Development of projects to develop renewable energy the whole day (night / day); } \\
\text { How to propose a consumption rate directly connected to the need? }\end{array}$ & 0 \\
\hline $\begin{array}{l}\text { Innovate through } \\
\text { sustainable way } \\
\text { of consumption }\end{array}$ & $\begin{array}{l}\text { How to directly link the production and the consumption of investors?; Proposal of } \\
\text { an offer to reduce the energy consumption, through a new business model; } \\
\text { fovelopment of a business model linking the invoicing template to the investment } \\
\text { stakeholders, in a long-term? }\end{array}$ & 5 \\
\hline $\begin{array}{l}\text { Innovate through } \\
\text { PSS }\end{array}$ & $\begin{array}{l}\text { Development of an offer to rent photovoltaic panels for users; Development of } \\
\text { new services to support self-consumption project; Development of services for the } \\
\text { reduction of energy consumption; Should the ownership of renewable energy } \\
\text { facilities remain at I-ENER? }\end{array}$ & 3 \\
\hline $\begin{array}{l}\text { Innovate through } \\
\text { territorial } \\
\text { resources }\end{array}$ & $\begin{array}{l}\text { Proposal of an offer adapted to the geographic location; Identification of resources } \\
\text { (water, sun, ..) locally available for a self-consumption project; Development of } \\
\text { an offer focused on territorial inhabitants for self-consumption; How to analyse the } \\
\text { geography of the territory to imagine new kinds of renewable energy? }\end{array}$ & 4 \\
\hline $\begin{array}{l}\text { Innovate through } \\
\text { circularity }\end{array}$ & $\begin{array}{l}\text { How to manage the end of life of photovoltaic panel?; How to integrate the end-of } \\
\text { life of photovoltaic panels in the business model? }\end{array}$ & 3 \\
\hline
\end{tabular}




\begin{tabular}{|l|l|c|}
\hline Innovate through & $\begin{array}{l}\text { Development of new renewable energy technology adapted for self-consumption } \\
\text { project; Development of a technology to directly inject low carbon energy on the } \\
\text { new technologies }\end{array}$ & $\begin{array}{l}\text { electric network only on time to avoid the use of high carbon energy; Looking for } \\
\text { new kinds of energy; How can the company propose the best available } \\
\text { technology?; Development of a second-hand market for photovoltaic panels }\end{array}$ \\
\hline
\end{tabular}

Table 5 displays conclusions concerning the direct examination of the ESM, and the reformulation of the problem, to choose the relevant ESMs for the eco-ideation session.

This method was considered relevant in supporting the group in exploring different pathways to start the eco-ideation session. The reformulation of the problematic with each ESM requires the group to open up the discussion and to imagine new possibilities to solve the problem. Moreover, the brief description of each ESM (see Table 1) was considered easy to understand.

Nevertheless, this methods requires the participants to make a real effort to translate the design task into each ESM, and for some of them, this reformulation was not an easy task (for example the ESM "Innovate through biomimicry"). Moreover, the group confirmed that the description of the ESM needs to be perfectly identical to facilitate its appropriation. To finish, one important weakness was that the group did not have a clear idea until which point ESMs were overlapping. For example, the stakeholder network was considered crucial for this design task. But participants did not know if the ESM "Innovate with territorial resources" integrated the notion of "territorial stakeholder network".

The main threat of this method is in line with literature. The group tends to explore the ESM they are familiar to ("Innovate with circularity", "innovate with sustainable mode of consumption"), even if they are not the more relevant for the design task.

Lastly an opportunity to strengthen this method is to clearly indicate the different features of each ESM, and the different "objects" that will be used during the eco-ideation session, to help the group remember some crucial aspects of the problem. Another opportunity revealed during this test was to envisage "extreme scenarios" for the design task (for example, what if self-consumption of energy is now compulsory), to support the group in choosing alternative ESM.

Table 5. SWOT analysis for the group 2 - direct examination of the ESMs

\begin{tabular}{|c|c|}
\hline Strengths & Weaknesses \\
\hline $\begin{array}{l}\text { This process supports the group in exploring } \\
\text { exhaustively the initial design brief. } \\
\text { The ESMs are easy to understand. }\end{array}$ & $\begin{array}{c}\text { Some ESM are not easy to adapt to the design } \\
\text { brief. } \\
\text { The formulation of the ESM are not the same. } \\
\text { Some ESM present overlapping features. }\end{array}$ \\
\hline Opportunities & \begin{tabular}{|c|} 
Threats \\
\end{tabular} \\
\hline $\begin{array}{l}\text { Identify and indicate the identical feature } \\
\text { between ESM to help the group to select the best } \\
\text { ESM. } \\
\text { Add examples for each ESM. } \\
\text { Identify the "extreme scenario". }\end{array}$ & $\begin{array}{l}\text { The skills and knowledge of participants clearly } \\
\text { influence the choice of the ESM. For example, } \\
\text { the ESM biomimicry was not identified because } \\
\text { of the lack of skill of the group. }\end{array}$ \\
\hline
\end{tabular}

\subsection{Method 3: Examination of inspiring examples}

After reading the cases, each participant made public his/her selection of cases and indicated why and to what extent cases were relevant for I-ENER. The aggregation of votes and comments of the 7 participants are summarized in Table 6. All the cases were grouped when redundant. Cases 11 Brooklyn Grid, 3 Power window and 10 Smiile were above the most cited cases among participants, whereas cases 2, 8 and 12 were discarded. Then the group clustered cases into four types of issues IENER has to face up with (Figure 3). Four reformulations of issues were emphasized as follows: (1) How should I-ENER diversify offers to face up with new demands for energy-related services?; (2) Could I-ENER optimize the service of photovoltaic panel installation, with additional systems?, (3) Could I-ENER move from a position of panel installer to an advisory position for self-consumption in communities?; (4) How is I-ENER currently positioned in the regional ecosystem of stakeholders, and what could be its future partners? The final selection of ESM was not operated thanks to the ESM provided on the cases, but based on the four clusters. The group finally agreed to focus on "Innovate 
with stakeholders", "Innovate through sustainable consumption modes" and "Innovate through Product Service Systems".

Table 6. Comments on selected cases for group 3

\begin{tabular}{|l|l|c|}
\hline \multicolumn{1}{|c|}{ Selected cases } & \multicolumn{1}{|c|}{ Justifications and comments } & $\begin{array}{c}\mathrm{Nb} \\
\text { of votes }\end{array}$ \\
\hline $\begin{array}{l}\text { 11/ Brooklyn } \\
\text { MicroGrid }\end{array}$ & $\begin{array}{l}\text { Management of energy, local energy market, new mission of management to help } \\
\text { individual citizens }\end{array}$ & 6 \\
\hline 3/ Powerwindow & $\begin{array}{l}\text { Ease of use, minor investments, but how to finance it? Attract new types of } \\
\text { clients }\end{array}$ & 5 \\
\hline 10/ Smiile & $\begin{array}{l}\text { Exchange energy on top of other services, share panels, promote the } \\
\text { empowerment of communities }\end{array}$ & 5 \\
\hline 9/ Effifuel & $\begin{array}{l}\text { Location of panels, windmill, I-ENER produces clean energy and becomes a } \\
\text { consultant, proposes multiple services, guarantees performances }\end{array}$ & 3 \\
\hline 14/ Amie & Development of an integrated system vision (home and transport) & 3 \\
\hline 1/ Aquakin & New application, location for camping, tourists & 2 \\
\hline 6/ Defab & Diversification of stakeholders, use other co-products & 2 \\
\hline 7/ Sun Saluter & Optimization of production. But is it relevant in Northern countries? & 1 \\
\hline 4/ Obiflam & Diversification of local production by using saw dust of Landes forest & 1 \\
\hline 5/ Glowee & Diversification, but warning on the exploitation of bacteria... & 2 \\
\hline
\end{tabular}

Table 7 reflects upon the relevance of examination of practical case studies to characterize the list of ESMs for eco-ideation. The main strength expressed is an interesting approach, easy to grasp and practical, but a long time is required to read through 14 cases. The individual selection phase followed by collective discussion was perceived as efficient.

The main weakness is the impression of "soilless inspiration" (quote from a participant), or a connection that was slightly lost with the I-ENER case because of the attractive power of illustrated cases. The approach is also very dependent on the initial sample of cases, which can be a limit. Moreover the actual selection phase of ESMs was too rapid and unstructured.

This opens up to opportunities of using a reduced sample of 10 cases, and more structured preferences for ESMs.

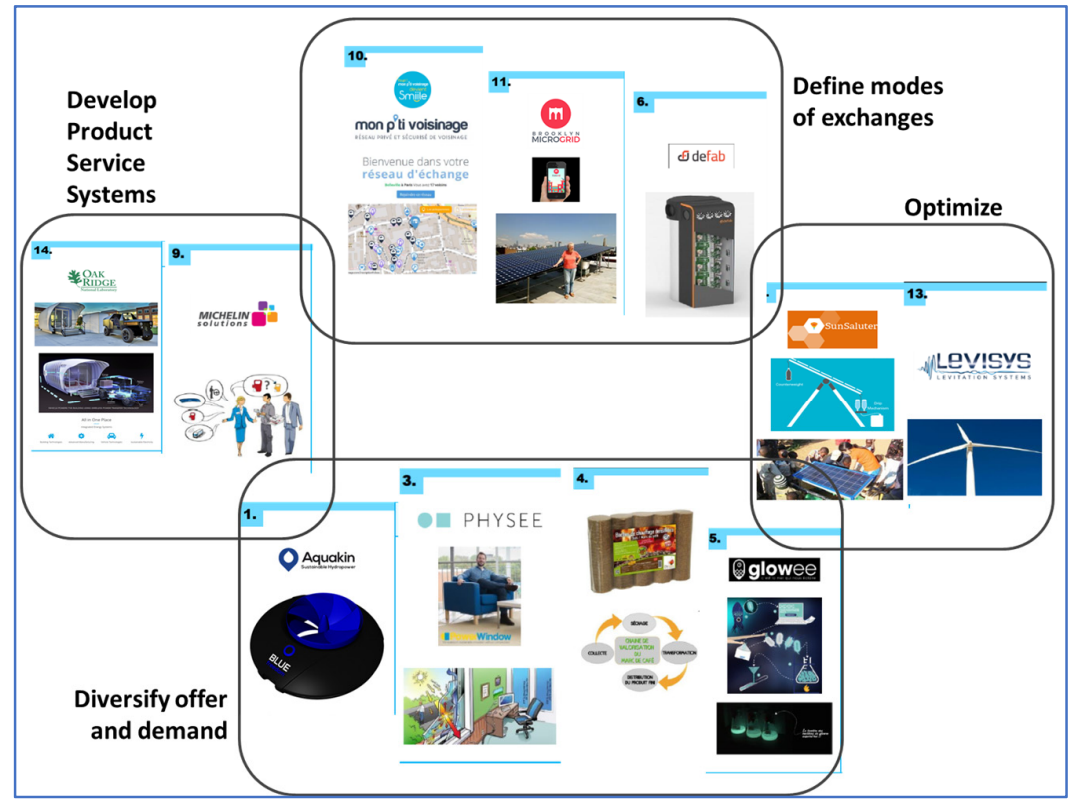

Figure 3. Clustering of selected cases for group 3 
Table 7. SWOT analysis of the group 3 - examination of inspiring examples

\begin{tabular}{|c|c|}
\hline Strengths & Weaknesses \\
\hline Practical cases are easy to grasp & Practical cases: how were they identified? \\
Large exploration & A too large number of cases to examine \\
Lost focus on the initial motivation \\
Adapted to various expertise of participants \\
Individual selection and collective discussion \\
Stakeholders are not around the table \\
Selection of mechanisms was not finalized
\end{tabular}

\subsection{Selection of appropriate ESMs and problem reformulation}

As a reminder, Sustainable consumption modes is cited by the 3 groups; Stakeholders are emphasized by groups 1 and 3, whereas Territorial resources appear in groups 1 and 2. Products Service Systems is finally chosen by group 3.The answers to the online questionnaire $(\mathrm{N}=14 / 20)$ confirm some remarks reported in the SWOT matrices. Even though respondents globally agree with choices made in their groups, they suggest that the selection was maybe too expected, and that less obvious ESMs for the brief (for instance "Innovate with Biomimicry") might lead, in the end, to more innovative solutions.

Regarding the depth of the reformulation, methods were compared through the examination of new questions raised during the session. The direct method 2 appears to be the more efficient in that sense (see Table 4). The description of blocks in method 1 gave the opportunity to raise about 10 questions on the life cycle and value chain level; the same amount of interrogations appeared with method 3, on a mixed organizational and technical level. Nevertheless, Group 3 felt less connected to the company realm than the other groups. The refinement of the eco-innovation brief is hence expected to prepare the eco-ideation phase.

\section{Conclusions and perspectives}

This paper continues on the lines of previous work undertaken on the characterization of eco-innovation (Vallet et al., 2017), and on Eco-ideation Stimulation Mechanisms (ESM) (Tyl et al., 2016).

Crossing references on eco-innovation, as well as innovation and creativity revealed the development of stimuli (or heuristics) is documented. However there is a gap when it comes to identify the appropriate stimuli related to an industrial brief, and to do the problem framing for eco-ideation. The research method is participant observation of groups of 20 practitioners trained in eco-design, eco-innovation or sustainability. Relying on the ESM concept, we proposed to test three methods to frame an industrial energy-based case study. The baseline method 1 connected ESMs to the analysis of environmental issues, while method 2 directly screened the case with the ESMs; method 3 examined a set of inspiring cases connected to the ESMs.

Results show that the overall selection of ESMs across groups is consistent, and rather expected regarding the topic (Innovate with sustainable consumption modes, with stakeholders, through territorial resources). Post-test reflections suggest that adding a less obvious ESM (for instance Innovate through Biomimicry) might bring more innovative opportunities as it increases the distance to the design task (Vasconcelos and Crilly, 2015). Lastly, the direct method 2 provided a large number of insightful questions for the reformulation of the problem. Examination of inspiring examples (method 3) and of environmental problems (method 2) also allowed reformulations, but to a lesser extent. The contribution is expected to be relevant for academia to teach eco-innovation, in higher education notably. This work indeed provides an inspirational example for framing eco-innovation in the case of a multi-level energy system, beyond the product-oriented examples of computer mouse and mobile phone in (Yang and Chen, 2011, 2012). It is also a pace toward an efficient implementation of eco-ideation in industrial contexts, where time and resources are constrained.

This paper dealt with the choice of relevant ESMs according to a design task. Future developments will consist in testing the ESMs during the whole idea generation stage. In a second part of the workshop, participants also tested the ESMs to generate eco-innovative ideas. Therefore, half-a day consisted in 
testing 4 ESMs on two other industrial case studies thanks to a specific board developed with the support of industrial designers (Figure 4).

The board represents the eco-ideation process with an intuitive and visual point of view, thanks to a set of cards. The process starts form a problematic card (in the centre of the board). From this card, users can develop a branch, representing an ESM (1). Each branch corresponds to 3 cards, corresponding to the three 3 main steps of the ESM. Then, the user can restart from the first problematic statement (2) and develop other branches, or follow the maturation of ideas with an additional ESM (3).

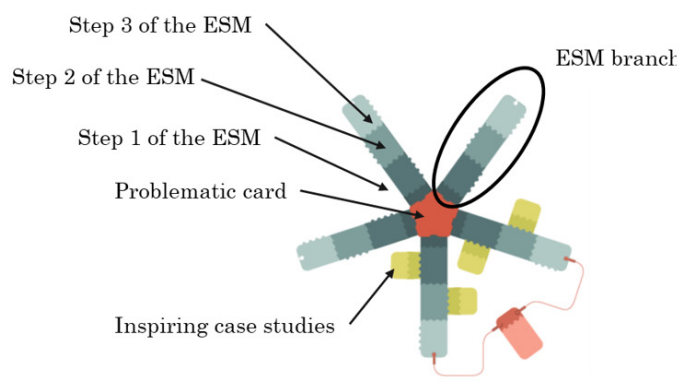

a) Principle of the ESM board

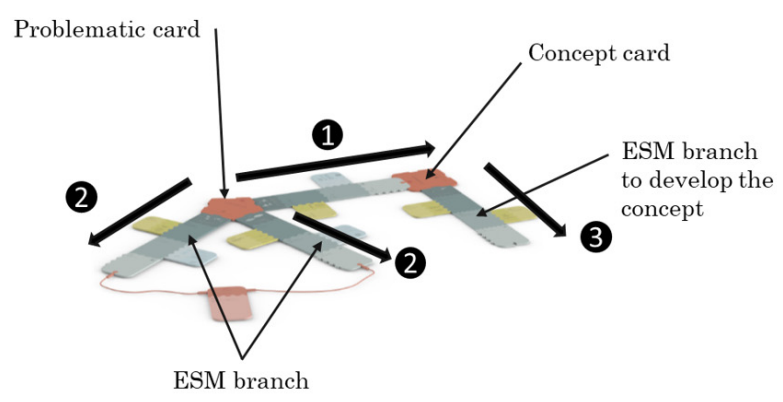

b) Development of the ESM board

Figure 4. Proposition of ESM board

Future work should clearly demonstrate the efficiency of the ESM to support an eco-innovation process, from the identification of the problem to the maturation of concepts.

Finally in line with the eco-centric spirit of eco-innovation (Hofstra and Huysingh, 2014), we support the idea that the ESM approach may give the opportunity to develop restorative, cyclical and even regenerative eco-innovative concepts, designed to "work with nature, and (can) restore, renew, revitalize and ensure 'rebirth' of their own sources of energy and materials by taking into account future needs, wants and desires of society and nature and by doing so within the natural systems of nature".

\section{Acknowledgment}

The authors express their gratitude to the participants to the workshop. They wish to thank the French National Research Agency (ANR) for the funding of the ALIENNOR project (reference: ANR-15-CE10-0001), as well as the Region Nouvelle Aquitaine, and the European Regional Development Fund. They also wish to thank the EcoSD network and the French environmental agency ADEME for their funding. This research work was carried out in the framework of the Technological Research Institute SystemX, and therefore granted with public funds within the scope of the French Program "Investissements d'Avenir".

\section{References}

Blessing, L.T.M. and Chakrabarti, A. (2009), DRM, a Design Research Methodology, Springer Science \& Business Media. https://doi.org/10.1007/978-1-84882-587-1

Bocken, N., Allwood, J., Willey, A. and King, J. (2011), "Development of an eco-ideation tool to identify stepwise greenhouse gas emissions reduction options for consumer goods", Journal of Cleaner Production, Vol. 19 No. 12, pp. 1279-1287. https://doi.org/10.1016/j.jclepro.2011.04.009

Bocken, N., Short, S., Rana, P. and Evans, S. (2014), "A literature and practice review to develop Sustainable Business Model Archetypes", Journal of Cleaner Production, Vol. 65, pp. 42-56. https://doi.org/10.1016/j.jclepro.2013.11.039

Brezet, H. and Van Hemel, C. (1997), Ecodesign: A Promising Approach to Sustainable Production and Consumption, UNEP, Paris.

Carrillo-Hermosilla, J., del Rio, P. and Könnöla, T. (2010), "Diversity of eco-innovations: Reflections from selected case-studies", Journal of Cleaner Production, Vol. 18 No. 10-11, pp. 1073-1083. https://doi.org/10.1016/j.jclepro.2010.02.014

Cluzel, F., Yannou, B., Millet, D. and Leroy, Y. (2016), "Eco-ideation and eco-selection of R\&D projects portfolio in complex systems industries", Journal of Cleaner Production, Vol. 112 No. 5, pp. 4329-4343. https://doi.org/10.1016/j.jclepro.2015.08.002 
Fussler, C. and James, P. (1996), Driving Eco-innovation: A Breakthrough Discipline for Innovation and Sustainability, Pitman Publishing, London.

Goldschmidt, G. and Smolkov, M. (2006), "Variances in the impact of visual stimuli on design problem solving performance”, Design Studies, Vol. 27 No. 5, pp. 549-569. https://doi.org/10.1016/j.destud.2006.01.002

Gonçalves, M., Cardoso, C. and Badke-Schaub, P. (2014), "What inspires designers? Preferences on inspirational approaches during idea generation", Design Studies, Vol. 35 No. 1, 29-53. https://doi.org/10.1016/j.destud.2013.09.001

Gonçalves, M., Cardoso, C. and Badke-Schaub, P. (2016), "Inspiration choices that matter: the selection of external stimuli during ideation", Design Science, Vol. 2. https://doi.org/10.1017/dsj.2016.10

Hellström, T. (2007), "Dimensions of environmentally sustainable innovation: the structure of eco-innovation concepts", Sustainable Development, Vol. 15 No. 3, pp. 148-159. https://doi.org/10.1002/sd.309

Hocking, I. and Vernon, D. (2017), "The right tool for the right task: Structured techniques prove less effective on an ill-defined problem finding task", Thinking Skills and Creativity, Vol. 26, pp. 84-91. https://doi.org/10.1016/j.tsc.2017.08.001

Hofstra, N. and Huysingh, D. (2014), "Eco-innovations characterized: a taxonomic classification of relationships between humans and nature", Journal of Cleaner Production, Vol. 66, pp. 459-468. https://doi.org/10.1016/j.jclepro.2013.11.036

Jonassen, D.H. and Hung, W. (2008), "All Problems are Not Equal: Implications for Problem-Based Learning", Interdisciplinary Journal of Problem-based Learning, Vol. 2. https://doi.org/10.7771/1541-5015.1080

JORF (2016), Ordonnance no 2016-1019 du 27 juillet 2016 relative a l'autoconsommation d electricite. [Online] JORF. Available at: https://www.legifrance.gouv.fr/eli/ordonnance/2016/7/27/DEVR1615431R/jo/texte (accessed 10.11.2017).

Mulet, E. and Vidal, R. (2008), "Heuristic guidelines to support conceptual design", Research in Engineering Design, Vol. 19 No. 2-3, pp. 101-112. https://doi.org/10.1007/s00163-008-0050-5

O’Hare, J.A., McAloone, T.C., Pigosso, D.C.A. and Howard, T.J. (2014), Eco-Innovation Manual - Tools instruction, United Nations Environment Programme, DTU.

Romli, A., Setchi, R., Soe, S. and Prickett, P. (2015), "Eco-case based reasoning (Eco-CBR) for supporting sustainable product design", SDM'2015: 2nd International Conference on Sustainable Design and Manufacturing, Seville, Spain, April 12-14.

Tyl, B., Legardeur, J., Millet, D. and Vallet, F. (2014), “A comparative study of ideation mechanisms used in eco innovation tools", Journal of Engineering Design, Vol. 25 No. 10-12, pp. 325-345. https://doi.org/10.1080/09544828.2014.992772

Tyl, B., Vallet, F., Bocken, N.M.P. and Real, M. (2015), "The integration of a stakeholder perspective into the front end of eco-innovation: a practical approach", Journal of Cleaner Production, Vol. 108, pp. 543-557. https://doi.org/10.1016/j.jclepro.2015.07.145

Tyl, B., Vallet, F., Pialot, O., Millet, D., Le Duigou, J. and Graves, G. (2016), “The ESM approach: 8 mechanisms to efficiently support eco-ideation", Proceedings of the DESIGN 2016, International Design Conference, Dubrovnik, Croatia, The Design Society.

United Nations, Department of Economic and Social Affairs, Population Division (2017), World Population Prospects: The 2017 Revision, Key Findings and Advance Tables. ESA/P/WP/248. [Online] UN. Available at https://esa.un.org/unpd/wpp/Publications/Files/WPP2017_KeyFindings.pdf (accessed 10.11.2017).

Vallet, F., Tyl, B., Pialot, O. and Millet, D. (2017), "Is this system eco-innovative? A case-based workshop", 21st International Conference on Engineering Design ICED17, The Design Society.

Vasconcelos, L.A. and Crilly, N. (2015), "Inspiration and fixation: Questions, methods, findings and challenges", Design Studies, Vol. 42, pp. 1-32. https://doi.org/10.1016/j.destud.2015.11.001

Yang, C.J. and Chen, J.L. (2011), "Accelerating preliminary eco-innovation design for products that integrates case-based reasoning and TRIZ method", Journal of Cleaner Production, Vol. 19 No. 9-10, pp. 998-1006. https://doi.org/10.1016/j.jclepro.2011.01.014

Yang, C.J. and Chen, J.L. (2012), "Forecasting the design of eco-products by integrating TRIZ evolution patterns with CBR and Simple LCA methods", Expert Systems with Applications, Vol. 39 No. 3, pp. 2884-2892. https://doi.org/10.1016/j.eswa.2011.08.150

Yilmaz, S., Daly, S.R., Seifert, C.M. and Gonzalez, R. (2015), "How do designers generate new ideas? Design heuristics across two disciplines”, Design Science, Vol. 1, pp. 1-29. https://doi.org/10.1017/dsj.2015.4

Dr. Benjamin Tyl

APESA, Innovation

PTCE, 23 Rue Hélène Boucher, 40220 Tarnos, France

Email: benjamin.tyl@apesa.fr 